\title{
AZ EMLŐDAGANATOK PRIMER SZISZTÉMÁS KEMOTERÁPIÁRA ADOTT VÁLASZA AZ IMMUNHISZTOKÉMIAI FENOTÍPUS TÜKRÉBEN
}

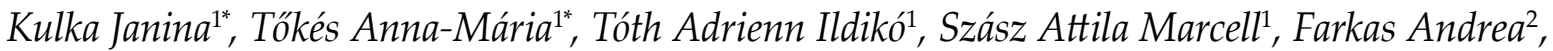 \\ Borka Katalin ${ }^{1}$, Járay Balázs ${ }^{1}$, Székely Eszter ${ }^{1}$, Istók Roland ${ }^{1}$, Lotz Gábor ${ }^{1}$, Madaras Lilla ${ }^{1}$, \\ Korompay Anna ${ }^{1}$, Harsányi László ${ }^{3}$, László Zsolt ${ }^{5}$, Rusz Zoltán ${ }^{6}$, Molnár Béla Ákos ${ }^{3}$, \\ Molnár István Arthur ${ }^{3}$, Kenessey István ${ }^{1}$, Szentmártoni Gyöngyvér ${ }^{4}$, Székely Borbála ${ }^{1,4}$, Dank Magdolna ${ }^{4}$ \\ ${ }^{1}$ Semmelweis Egyetem, II. sz. Patológiai Intézet; ${ }^{2}$ Fővárosi Önkormányzat, Szent Imre Kórház; ${ }^{3}$ Semmelweis Egyetem, I. sz. Sebészeti \\ Klinika; ${ }^{4}$ Radiológiai és Onkoterápiás Klinika; ${ }^{5}$ MaMMa Klinika Budapest; ${ }^{6}$ Schöpf-Merei Kórház Sebészeti Osztály, Budapest
}

$1^{*}$ - egyenlő mértékben járultak hozzá a közleményhez

\begin{abstract}
A neoadjuváns kemoterápiára adott patológiai választ kívántuk elemezni az emlőtumorok immunhisztokémiai fenotípusai, valamint az alkalmazott kemoterápiás protokollok tükrében. 1998 és 2009 között 92 neoadjuváns kezelésen átesett emlötumoros nőbeteg klinikai adatait, biopsziás és mütéti anyagát valamint túlélési mutatóit vizsgáltuk. A biopsziás- és mütéti anyagokon hormonreceptor (ER, PgR), Ki-67, p53, HER2 státusz meghatározás történt immunhisztokémiai módszerrel. A patológiai válasz megitélésére a Chevallier-osztályozást használtuk. 88 esetben elemeztük a betegségmentes-és a teljes túlélést a patológiai válasz függvényében. Patológiai komplett remisszió ( $p C R=$ Chevallier I és II) volt kimutatható $13 / 92$ esetben $(14,1 \%)$. A preoperatív daganatjellemzók alapján a patológiai komplett remissziót mutató daganatok a tripla negatív (9/13) valamint az ER-/HER2+ (1/13) és az ER+/HER2+ (3/13) csoportokból kerültek ki. 24 beteg részesült taxán-, 30 antraciklin-, 33 taxán+antraciklin alapú terápiában, 2 CMF típusú neoadjuváns kezelésben, 3 esetben nem állt rendelkezésünkre ez az adat. A taxánnal kezelt betegek 29,1\%-ában, az antraciklin-származékkal kezelt betegek 6,6\%-ában, a kombinált kezelésben részesült betegek 12,1\%-ában volt kimutatható $p C R$. A $p C R$-t mutató csoportban kevesebb volt a recidíva és a távoli áttét kialakulása, de nem tudtunk szignifikáns különbséget igazolni. A kezelésre reagáló (Chevallier III) és a nem reagáló (Chevallier IV) csoport között ebben a tekintetben szignifikáns különbséget találtunk $(p=0,006)$. A betegségspecifikus halálozás szignifikánsan alacsonyabb volt a $p C R$ betegcsoportban $(p=0,050)$. Eredményeink alapján a patológiai komplett remissziót mutató esetek a tripla negatív és a HER2-pozitív csoportból kerültek ki. A neoadjuváns kezelés az ER+l HER2- tumorcsoportban volt a legkevésbé hatékony. Magyar Onkológia 53:335-343, 2009
\end{abstract}

Kulcsszavak: neoadjuváns terápia, primer szisztémás terápia, emlőrák, fenotípus

The purpose of the study was to identify breast cancer subtypes by immunohistochemistry likely to respond to neoadjuvant chemotherapy and to analyze the used chemotherapy regimen and the range of response rates. Analysis of a collected database was performed. Ninety-two patients were identified in our files who received neoadjuvant chemotherapy between 1998 and 2009. We used immunohistochemical profiles (ER, PgR, HER2, Ki-67 and p53) of NCB, FNAB and surgical breast specimens to subclassify the tumors. Pathological response rates were assessed following surgical removal of tumors by using the Chevallier classification. DFS and OS was measured in 88 cases from the date of definitive surgery to the date of last follow-up or death. Pathological complete or near-complete remission ( $p C R=$ Chevallier I and II) was observed in 13 of 92 cases (14.1\%). According to the preoperative characteristics of the 13 tumors achieving $p C R, 9$ of the cases were triple negative, one of 13 was ER-/HER2+ and three of 13 ER+/HER2+. Twenty-four of 92 patients received taxane based neoadjuvant chemotherapy, 30 of 92 anthracyclin based neoadjuvant chemotherapy, 33 of 92 taxane + anthracyclin regimen and 2 of $92 C M F$ regimen. In the taxane treated group of patients the $p C R$ rate was $29.1 \%$, in the anthracyclin group $6.6 \%$ and in the taxane + anthracyclin treated group $12.1 \%$. Concerning DFS, significant difference was observed between the Chevallier III and IV groups ( $p=0.006)$, and less events were observed in the $p C R$ group (not significant). $p C R$ was associated with significantly better OS ( $p=0.050$ ). It seems that even limited, routinely used immunohistochemical profiling of tumors is able to predict the likelihood of $p C R$ to neoadjuvant chemotherapy. Patients with triple negative and HER2-positive cancers are likely to achieve $p C R$ after neoadjuvant chemotherapy. Kulka J, Tőkés A-M, Tóth AI, Szász AM, Farkas A, Borka K, Járay B, Székely E, Istók R, Lotz G, Madaras L, Korompay A, Harsányi L, László Z, Rusz Z, Molnár BÁ, Molnár IA, Kenessey I, Szentmártoni Gy, Székely B, Dank M: Immunohistochemical phenotype of breast carcinomas predicts the effectiveness of primary systemic therapy. Hungarian Oncology 53:335-343, 2009

Keywords: neoadjuvant therapy, primary systemic therapy, breast cancer, phenotype
Közlésre érkezett: 2009. október 30 .

Elfogadva:

2009. november 20

Levelezési cím:

Dr. Kulka Janina

Semmelweis Egyetem

II. sz. Patológiai Intézet

1091 Budapest

Üllői út 93.

Telefon:

(06-1) 2157-300/53430

Fax: (06-1) 215-6921

E-mail: kj@korb2.sote.hu

Röviditések:

pCR: patológiai komplett remisszió;

TE: docetaxel + epirubicin;

FEC: 5-fluorouracil + epirubicin + cytoxan; FAC: 5-fluorouracil + adriamycin + cytoxan; CMF: ciklofoszfamid + metotrexát + 5-fluorouracil; TC: docetaxel + carboplatin; 2wAD: 2 hetente adott adriamycin + docetaxel; EWGBSP: European Working Group of Breast Screening Pathologists

Munkánkhoz az alábbi pályázatok forrásait használtuk: NKFP-1A/0023/2002, AVON-EAGC 2005, MKOT-GSK 2006, MKOT-GSK 2008 TVKEB 139/2009 


\section{BEVEZETÉS}

A neoadjuváns, más néven primer szisztémás kemoterápia (PST) eredeti célja nagyméretü, lokálisan kiterjedt tumor reszekabilitásának, illetve operabilitásának elérése volt $(21,23)$. Gyulladásos emlőrák esetén a mai napig ez jelenti az ellátást. Az 1990-es évektől kezdődően a korai stádiumú tumorok terápiájában is szerepet kapott, mivel indikációs köre a daganatok biológiai viselkedésének egyre pontosabb megismerése révén folyamatosan bővült. A korai stádiumú emlőcarcinomák esetében az alábbi tapasztalatok indokolják a PST alkalmazását:

- növelheti az emlőmegtartó műtétek számát és lehetőségét (39)

- patológiai remisszió elérésével és/vagy a nyirokcsomókban lévő mikrometasztázisok eltünésével a betegség alacsonyabb stádiumba jut (ún. down-staging) (19) - in vivo információ nyerhető a daganatsejtek kemoterápiás szer iránti érzékenységéről (19)

Több közlemény elemzi, hogy a neoadjuváns terápia alkalmazása különösen patológiai komlett remisszió (pCR) esetén

- meghosszabbíthatja a betegek össz-túlélését (overall survival - OS) és

- meghosszabbíthatja a tünetmentes periódust (diseasefree survival - DFS) $(2,3,11,39)$

Az utóbbi években számos közlemény taglalja a neoadjuváns kemoterápia szerepét és eredményességét az emlőtumorok kezelésében $(29,32)$. Az eredmények rutinszerü értékelésére különböző kritériumrendszerek születtek. Megkülönböztetünk klinikai és patológiai választ. A klinikai válasz megítélésére a legelterjedtebb módszer az UICC által kidolgozott séma (16), míg a patológiai válasz megítélésére többféle módszer is létezik. Ez az eredmények értékelésében ellentmondást okozhat. A legelterjedtebb patológiai értékelési rendszerek a Miller és Payne által kidolgozott ötfokozatú rendszer (25), a Chevallier, a Sataloff és a Feldman által kidolgozott módszerek $(8,10,34)$. A neoadjuváns kemoterápia alkalmazásakor a pCR elérése az optimális cél, mivel ez bizonyult a legjobb túlélést előrejelző faktornak több vizsgálat alapján is $(5,30)$. A klinikai és a patológiai válasz értékelésének kritériumai nagymértékben különböznek egymástól. Ennek egyik oka a terápiára adott válasz mérésének eltérő módszereiben keresendő. Míg a klinikai tumorméret meghatározása fizikális vizsgálattal, UH-, rtg- és MR-mammográfiával, addig a patológiai méret meghatározása a reziduális daganat mikroszkópos kiterjedése - metszeteken mérhető mérete alapján történik. A szövettanilag hasonló emlőtumorok eltérő választ adnak a preoperatív szakaszban alkalmazott kemoterápiára. Irodalmi adatok és a saját tapasztalataink szerint a neoadjuváns kemoterápiára reagáló emlőtumorokban jellegzetes, a kezelés hatására létrejövő mennyiségi és minőségi változások alakulnak ki a stromában is (37). Az azonos hatóanyag alapú kezelésre adott eltérő patológiai válasz hátterében az emlődaganatok eltérő genetikai profilja állhat. Irodalmi adatok alapján öt különböző emlőtumor-altípus különíthető el a genetikai profil tükrében (luminalis A, luminalis B - ER-pozitív szubtípusok, basalis - ER-, PgR-, HER2-, HER2-pozitív és ún. ",normal breast like” - ER-negatív szubtípusok). Az altípusok közül jó közelítéssel az immunhisztokémiai tulajdonságaik alapján is felismerhető a luminalis A, B, HER2-pozitív és a tripla negatív típus. Az altípusok elkülönítése az alkalmazott terápia szempontjából is fontos, mivel a tripla negatív tumorok esetében a kemoterápiás kezelésen kívül kevés, még csak kísérleti fázisban lévő „célzott“ kezelési protokoll létezik, szemben az ER-pozitív vagy HER2pozitív tumorokkal. Az eddigi tapasztalatok alapján az ER-pozitív tumorok döntő többsége nem mutat jelentős regressziót neoadjuváns kemoterápiát követően $(33,35,36)$. Az egyidejűleg ER-, PgR- és HER2-negatív (tripla negatív) tumorok egy része a basalis szubtípusra jellemző CK5/6-pozitivitást hordozza, és ezek a daganatok rosszabb prognózissal bírnak $(6,30)$. Azonban irodalmi adatok alapján a pCR-t mutató tumorok nagy része ebből az altípusból kerül ki $(22,38)$. Számos elemzést végeztek annak megállapítására, hogy milyen összefüggés figyelhető meg a pCR - különböző daganataltípus - betegségmentes túlélés hossza, valamint a pCR - daganataltípus - teljes túlélés hossza között (22). Több munkacsoport eredményei szerint annak ellenére, hogy az ER-negatív daganatok esetén nagyobb arányban figyelhető meg pCR, ebben a csoportban a tünetmentes periódusok rövidebbek, mint az ER-pozitív csoportban (17, 31, 32). Számos tanulmány eredménye jelenik meg a preoperatívan alkalmazott kemoterápiás szerek hatékonyságával kapcsolatban is $(13,26)$.

Kevés hazai irodalmi adattal rendelkezünk a neoadjuváns kemoterápia alkalmazásáról, eredményességéról emlőtumorokban $(9,19)$. Munkánkban elemezzük az 1998 és 2009 között a Semmelweis Egyetem II. sz. Patológiai Intézetében vizsgált, a Radiológiai Klinika Onkoterápiás Osztályán neoadjuvánsan kezelt emlőtumorokat, a daganatok immunhisztokémiai fenotípusa alapján megállapított szubtípusai, az alkalmazott kemoterápiás protokollok, valamint a patológiai válaszok tükrében.

\section{BETEGANYAG ÉS VIZSGÁLATOK}

A Semmelweis Egyetem I. sz. Sebészeti Klinikával és a Radiológiai és Onkoterápiás Klinikával együttmüködve 1998-tól 2009-ig értékeltük 92 neoadjuvánsan kezelt emlődaganatos beteg klinikai adatait, valamint biopsziás és mütéti anyagát. Az alkalmazott kemoterápiás protokollok TE, FAC / FEC, TC és CMF voltak.

A tíz éves periódusban változtak az alkalmazott kemoterápiás protokollok. A betegek többsége antraciklin- és/vagy taxán-alapú terápiát kapott. Az 
1. táblázat. Klinikai és patológiai jellemzők a kezelés előtt és után

\begin{tabular}{|c|c|}
\hline Klinikai T stádium & Esetszám \\
\hline T1 & 21 \\
\hline T2 & 40 \\
\hline T3 & 15 \\
\hline $\mathrm{T} 4$ & 16 \\
\hline \multicolumn{2}{|l|}{ Core/FNAB diagnózis } \\
\hline IDC & 60 \\
\hline ILC & 3 \\
\hline Carcinoma NOS & 18 \\
\hline Mastitis carcinomatosa & 5 \\
\hline Egyéb & 3 \\
\hline Nincs adat & 3 \\
\hline \multicolumn{2}{|l|}{ Preoperatív grade } \\
\hline 1 & 7 \\
\hline 2 & 32 \\
\hline 3 & 34 \\
\hline Nincs megadva & 19 \\
\hline \multicolumn{2}{|l|}{ Mütét típusa } \\
\hline Emlőmegtartó & 44 \\
\hline Radikális & 47 \\
\hline Subcután mastectomia & 1 \\
\hline \multicolumn{2}{|c|}{$\begin{array}{l}\text { Patológiai T stádium a mútét utáni szövet- } \\
\text { tani vizsgálat alapján }\end{array}$} \\
\hline $\mathrm{Tx}^{*}$ & 2 \\
\hline T0 & 14 \\
\hline Tis & 2 \\
\hline $\mathrm{T} 1$ & 32 \\
\hline $\mathrm{T} 2$ & 30 \\
\hline T3 & 6 \\
\hline $\mathrm{T} 4$ & 6 \\
\hline
\end{tabular}

* reziduális tumorsejtek csak néhány nyirokúton belül voltak láthatóak

adatok a valós élet kezelési szokásait tükrözik: a terápia nem "homogén". Ezért is tartottuk fontosnak, hogy nem "trial" körülmények között zajló kezeléseket értékeljünk. A rendelkezésünkre álló adatbázisok alapján az emlőcarcinoma diagnózis core-biopszia, FNAB vagy mindkettő segítségével történt. A preoperatív diagnózis alapján 60 invazív ductalis carcinoma, 18 invazív carcinoma (külön megjelölés nélkül), 3 invazív lobularis carcinoma, 3 más típusú carcinoma került elemzésre. Öt esetben - a klinikai képet alátámasztva - a biopsziás mintában mastitis carcinomát igazoltunk. Három beteg esetében más intézetben történt a diagnosztikus biopszia. A klinikai TNM-beosztás alapján T1-T4, N0 vagy N1, M0 betegek részesültek neoadjuváns kezelésben. Tizenhat beteg esetében klinikailag gyulladásos emlőrák indokolta a primer szisztémás kezelést (1. táblázat). Az FNAB mintákon esetenként hormonreceptor - ösztrogénreceptor (ER) és progeszteronreceptor (PgR), valamint HER2, a core-biopsziás anyagokon hormonreceptor (ER, PgR) meghatározás valamint a Ki-67, p53, citokeratin 5/6 (CK5/6) és HER2 kimutatása történt immunhisztokémiai módszerrel. A neoadjuváns kezelést követően, a mútéti preparátum feldolgozása során szintén ezeket a daganatjellemzőket vizsgáltuk. Az adatokat Microsoft Excel táblázatban rögzítettük.

88 esetben rendelkezünk betegkövetési adatokkal. A betegkövetés során a loko-regionális recidíva és távoli áttét helyét és idejét jegyeztük fel. A lokális tumorkontroll, az emlőrák-specifikus túlélés és a relapszusmentes túlélés tartamát a mútét napjától számítottuk. A túlélések valószínűségét Kaplan és Meier (20) módszerével számítottuk.

\section{A neoadjuváns terápiára adott válasz megitélése}

A terápiára adott válasz vizsgálatához a szövettani elemzéssel meghatározott tumorméret tekinthető a legpontosabb eljárásnak, ún. gold standardnak. Különböző kritériumrendszerek születtek a patológiai válasz meghatározására. Munkánkban a Chevallier-féle, illetve a Sataloff-féle beosztást alkalmaztuk (2. táblázat). Az eredmények értékelése az átláthatóság miatt csak a Chevallier osztályozás alapján történt. Alapvető különbség a két rendszer között, hogy míg a Chevallier-beosztás az elsődleges daganatot és a hónalji nyirokcsomó-státuszt is egy kombinált skálán veszi figyelembe, addig a Sataloffrendszer külön méri a primer tumor és az axillaris áttétek változását. A Chevallier-féle klasszifikáció I-es csoportja semmilyen reziduális tumort nem enged meg, itt a patológiai teljes remisszió teljes tumormentességet jelent, míg a Sataloff-csoportosításban szereplő T-A csoportba tartozó tumor a Chevallier II-es csoportba is tartozhat, amennyiben reziduális in situ carcinoma igazolódik, de a hónalji nyirokcsomók tumormentesek. Egy vizsgálat (27), mely a Sataloff-és Chevallier-osztályozást hasonlította össze a tumorregresszió és így a prognózis megítélése szempontjából, közel azonos értékűnek találta a két rendszert.

2. táblázat. A primer tumorra vonatkozó patológiai válasz kritériumai a Chevallier-, illetve a Sataloff-osztályozás szerint

\begin{tabular}{|c|c|c|c|}
\hline $\begin{array}{l}\text { Chevallier- } \\
\text { osztályozás }\end{array}$ & Jellemzők & $\begin{array}{l}\text { Sataloff- } \\
\text { osztályozás }\end{array}$ & Jellemzők \\
\hline I & $\begin{array}{l}\text { Nincs reziduális tumor az emlőben és az axillaris nyirokcsomók- } \\
\text { ban }\end{array}$ & T-A & $\begin{array}{l}\text { Komplett remisszió: DCIS } \\
\text { megengedett }\end{array}$ \\
\hline II & DCIS, nyirokcsomók negatívak & T-B & $>50 \%$-os terápiás hatás \\
\hline III & Invazív tumor, stromalis fibrózissal (látható változás) & $\mathrm{T}-\mathrm{C}$ & $<50 \%$-os terápiás hatás \\
\hline IV & Nincs vagy elenyésző változás & T-D & Hatástalan kezelés \\
\hline
\end{tabular}


Immunhisztokémiai vizsgálatok az ER-, PgRés HER2-kifejeződés kimutatásához

Az immunhisztokémiai vizsgálatokat FNAB keneteken, valamint formalinfixált, paraffinba ágyazott 3-5 $\mu \mathrm{m}$ vastag metszeteken végeztük a 3. táblázatban ismertetett ellenanyagokkal és módszerekkel. Jelen munkánkban az ER, PgR és HER2 kifejeződésének részletes elemzését végeztük el.

Az immunhisztokémiai reakciók Ventana ES immunfestő automatával készültek (Ventana Medical Systems Inc., Tucson, AZ, USA), kromogénként 3,3-diamino-benzidint (DAB) alkalmaztunk, míg a háttérfestést hematoxilinnel végeztük.

A HER2-amplifikáció igazolására FISH-vizsgálatokat végeztünk 22 preoperatív mintán (19 core-biopszia és 3 FNAB), valamint 41 posztoperatív mintán fluoreszceinjelölt HER2-próbával, Ventana automata segítségével.

\section{Az immunhisztokémiai reakciók értékelése}

ER és PgR esetében a $>10 \%$ magpozitivitást mutató eseteket értékeltük pozitívnak. (Az Allred score meghatározására csak az utóbbi két évben tértünk át, ezért használtuk ezt a küszöbértéket.) A HER2 immunhisztokémiai reakció értékelése a standard diagnosztikus eljárás lépései szerint történt (15). Az 1+ esetek negatívak, a 2+ eseteket akkor értékeltük pozitívnak, ha FISH-reakcióval igazolható volt a HER2-amplifikáció, míg a 3+ eseteket FISHverifikáció nélkül is pozitívnak értékeltük. Mivel nem volt olyan esetünk, ahol a HER2 immunhisztokémiai reakcióval kifejezett, körkörös membránpozitivitást mutató daganatsejtek aránya 30\%-nál kisebb lett volna, az időközben megváltozott értékelési séma nem befolyásolja eredményeinket (40).

\section{Statisztikai vizsgálatok}

A kontingenciatáblák változói közötti összefüggést a viszonylag alacsony esetszámok miatt Monte Carlo teszttel vizsgáltuk, szignifikánsnak a $\mathrm{p}<0,05$ értéket vettük. Az analízist Past 1.86 b és SPSS 15.0 programmal végeztük el.

\section{EREDMÉNYEK}

Mind a 92 esetünkben elemeztük a neoadjuváns terápia hatását a primer emlőtumorokban az immunhisztokémiai módszerrel elkülöníthető emlőtumoraltípusokkal (luminalis A, luminalis B - ER-pozitív altípusok, tripla negatív (ER-, PgR-, HER2-), HER2-pozitív,

3. táblázat. Az alkalmazott ellenanyagok és feltárási protokollok

\begin{tabular}{|c|c|c|c|}
\hline Ellenanyag neve & $\begin{array}{l}\text { Forgalmazó cég, } \\
\text { ellenanyagklón }\end{array}$ & $\begin{array}{c}\text { Antigénfeltárás } \\
\text { paraffinba ágyazott metszetek esetében }\end{array}$ & Antigénfeltárás FNAB keneteken \\
\hline ER & Novocastra, 6F11 & $\begin{array}{l}\text { TRIS-EDTA, } \\
30 \text { perc mikrohullámon }\end{array}$ & $\begin{array}{l}\text { Vector antigen retrieval solution, } \\
6 \text { perc }\end{array}$ \\
\hline $\operatorname{PgR}$ & Novocastra, 312 & $\begin{array}{l}\text { Vector antigen retrieval solution, } \\
12 \text { perc mikrohullámon }\end{array}$ & $\begin{array}{l}\text { Vector antigen retrieval solution, } \\
6 \text { perc mikrohullámon }\end{array}$ \\
\hline HER2 & Novocastra, CB11 & $\begin{array}{l}\text { Vector antigen retrieval solution, } \\
30 \text { perc mikrohullámon }\end{array}$ & Nem alkalmaztunk \\
\hline $\mathrm{Ki}-67$ & DAKO, MIB1 & $\begin{array}{l}\text { TRIS-EDTA, } \\
30 \text { perc mikrohullámon }\end{array}$ & $\begin{array}{l}\text { Vector antigen retrieval solution, } \\
6 \text { perc mikrohullámon }\end{array}$ \\
\hline p53 & DAKO, DO-7 & $\begin{array}{l}\text { TRIS-EDTA, } \\
30 \text { perc mikrohullámon }\end{array}$ & $\begin{array}{l}\text { Vector antigen retrieval solution, } \\
6 \text { perc mikrohullámon }\end{array}$ \\
\hline
\end{tabular}

4. táblázat. HER2-, ER-és PgR-meghatározás és összehasonlitás preoperatív és posztoperatív mintákon

\begin{tabular}{|c|c|c|c|c|c|c|c|c|c|c|c|c|}
\hline & \multicolumn{2}{|c|}{$\begin{array}{l}\text { HER2 } \\
\text { preop. }\end{array}$} & \multicolumn{2}{|c|}{$\begin{array}{l}\text { HER2 } \\
\text { posztop. }\end{array}$} & \multicolumn{2}{|c|}{$\begin{array}{l}\text { ER } \\
\text { preop. }\end{array}$} & \multicolumn{2}{|c|}{$\begin{array}{c}\text { ER } \\
\text { posztop. }\end{array}$} & \multicolumn{2}{|c|}{$\begin{array}{l}\text { PgR } \\
\text { preop. }\end{array}$} & \multicolumn{2}{|c|}{$\begin{array}{c}\text { PgR } \\
\text { posztop. }\end{array}$} \\
\hline & Poz. & Neg. & Poz. & Neg. & Poz. & Neg. & Poz. & Neg. & Poz. & Neg. & Poz. & Neg. \\
\hline Van reziduális tumor & 20 & 55 & 26 & 53 & 39 & 37 & 45 & 34 & 27 & 47 & 25 & 53 \\
\hline Hiányzó preop. adat & \multicolumn{2}{|c|}{$\begin{array}{l}\text { Nincs adat } \\
\text { (17 eset) }\end{array}$} & 9 & 8 & \multicolumn{2}{|c|}{$\begin{array}{l}\text { Nincs adat } \\
\text { (16 eset) }\end{array}$} & 8 & 8 & \multicolumn{2}{|c|}{$\begin{array}{l}\text { Nincs adat } \\
\text { (18 eset) }\end{array}$} & 5 & 13 \\
\hline $\begin{array}{l}\text { Nincs reziduális tumor } \\
(\mathrm{pCR})\end{array}$ & 4 & 9 & \multicolumn{2}{|c|}{$\begin{array}{l}\text { pCR miatt nem } \\
\text { értékelhető (13) }\end{array}$} & 3 & 10 & \multicolumn{2}{|c|}{$\begin{array}{l}\mathrm{pCR} \text { miatt nem } \\
\text { értékelhető (13) }\end{array}$} & 1 & 12 & \multicolumn{2}{|c|}{$\begin{array}{l}\text { pCR miatt nem } \\
\text { értékelhető (13) }\end{array}$} \\
\hline Hiányzó posztop. adat & 0 & 0 & Ninc & dat $(0)$ & 0 & 0 & Ninc & lat (0) & 1 & 0 & Ninc & dat (1) \\
\hline
\end{tabular}


5. táblázat. A neoadjuvánsan alkalmazott terápiára bekövetkezett patológiai válasz megitélése a Chevallier-osztályozás alapján,

a különböző hatásmechanizmusú terápiás protokollok függvényében

\begin{tabular}{lcc}
\hline $\begin{array}{c}\text { Alkalmazott kezelés } \\
\text { (kezelt esetszám) }\end{array}$ & $\begin{array}{c}\text { Chevallier I-II } \\
\text { esetszám (arány) }\end{array}$ & $\begin{array}{c}\text { Chevallier III-IV } \\
\text { esetszám (arány) }\end{array}$ \\
\hline Antraciklin (30) & $2(6,6 \%)$ & $28(93,6 \%)$ \\
Taxán (24) & $7(29,1 \%)$ & $17(70,9 \%)$ \\
Antraciklin + taxán (33) & $4(12,1 \%)$ & $29(87,9 \%)$ \\
Egyéb (CMF) (2) & 0 & $2(100 \%)$ \\
Nem ismert (3) & 0 & $3(100 \%)$ \\
P (Monte Carlo) & 0,215 & $<0,001$ \\
\hline
\end{tabular}

ER-negatív altípusok), illetve a különböző hatásmechanizmusú kemoterápiás protokollokkal összefüggésben (4. és 5. táblázat).

A betegek átlagos életkora 52,8 év volt (min. 27 - max. 79). Öt beteg 30 éves vagy fiatalabb, további 34 beteg 50 év alatti volt a diagnózis idején. 24 beteg taxán-, 30 beteg antraciklin-, 33 beteg kombinált taxán+antraciklinalapú kezelésben részesült. 2 beteg CMF kezelést kapott. Három esetben nem áll rendelkezésünkre kezelési adat, a betegek mütétre kerültek az I. sz. Sebészeti Klinikára, és a posztoperatív szövettani vizsgálat történt a II. sz. Patológiai Intézetben. A trastuzumab neoadjuvánsan történő alkalmazása még nem része a napi rutinnak, noha a rendelkezésre álló adatok alapján alkalmazása a HER2-overexpressziót/amplifikációt mutató tumorokban igen ígéretes (szerző megjegyzése) $(1,4,12)$. A betegek medián követési ideje 38 hónap (6-137 hónap) volt, ahol eseményként a recidíva, illetve távoli áttétek megjelenését, valamint a betegségspecifikus halálozást

Betegségmentes túlélés

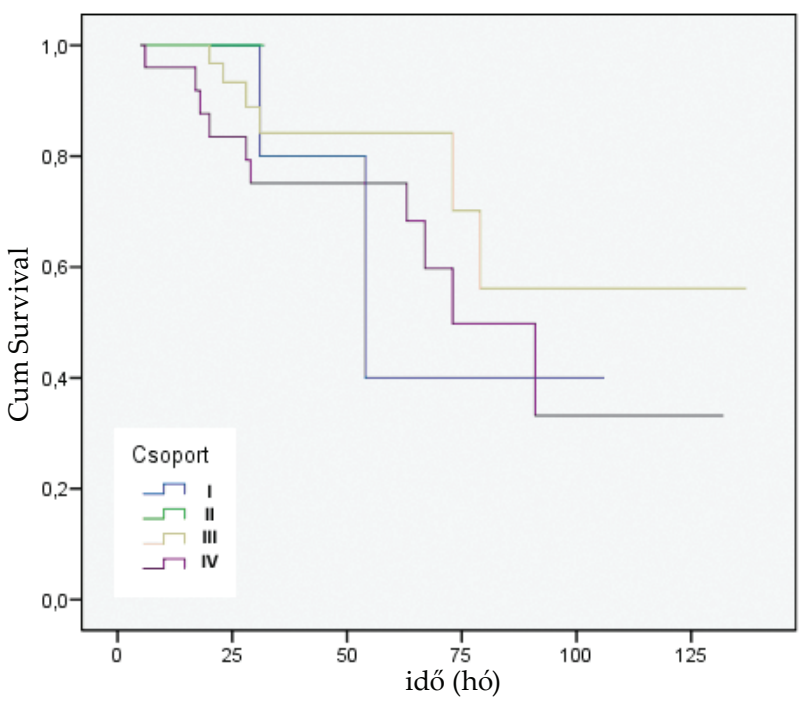

1. ábra. Betegségmentes túlélés elemzése a különböző patológiai válaszreakciót mutató betegcsoportokban

a Chevallier-osztályozás alapján. Kaplan-Meier módszer: I+II vs. III $p=0,126$, III vs. IV $p=0,006$
Teljes túlélés

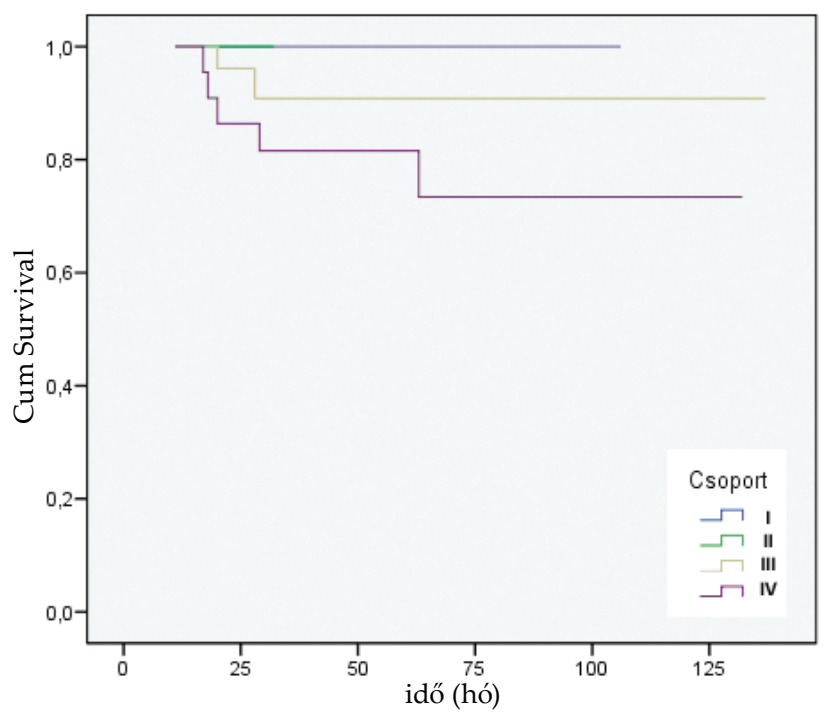

2. ábra. Teljes túlélés vizsgálata a különböző patológiai válaszreakciót mutató betegcsoportokban a Chevallier-osztályozás alapján. Kaplan-Meier módszer: I+II vs. III p=0,050, III vs. IV p=0,032

vettük figyelembe. A követés alatt a pCR-t mutató betegcsoportban (13 beteg) emlőrákkal összefüggő eseményt 2 esetben észleltünk (recidíva), míg haláleset a követés lezárásáig nem történt. A Chevallier III-as csoportba sorolt betegek esetében ( 50 beteg) 5 esetben alakult ki távoli áttét, 1 esetben recidíva, 2 esetben exitus történt. A neoadjuváns kemoterápiára nem reagáló betegcsoportban (Chevallier IV) (25 beteg) 10 esetben alakult ki távoli metasztázis és 5 haláleset történt (1 és 2. ábra).

A 3. ábrán a vizsgált tumorokat egyenként ábrázolva a T stádium változását és a változás mértékét tüntettük fel ("delta T") A kiinduló klinikai stádiumot 0 pontnak tekintve és végpontként a mütéti anyagban megállapított patológiai $\mathrm{T}$ stádiumot figyelembe véve látható, hogy mindössze 9 beteg esetében észleltük a kiindulási cT stádium és a pT stádium pozitív irányú eltérését. A képalkotó vizsgálatok ezeknél a betegeknél azonban stabil állapotot mutattak. 83 beteg esetében „downstaging" következett be.

$\mathrm{Az}$ antraciklin-alapú kezelésben részesült betegek $6,6 \%$-ában (2/30) a kezelés hatására komplett vagy közel komplett remisszió jött létre (Chevallier I és II). A taxán-

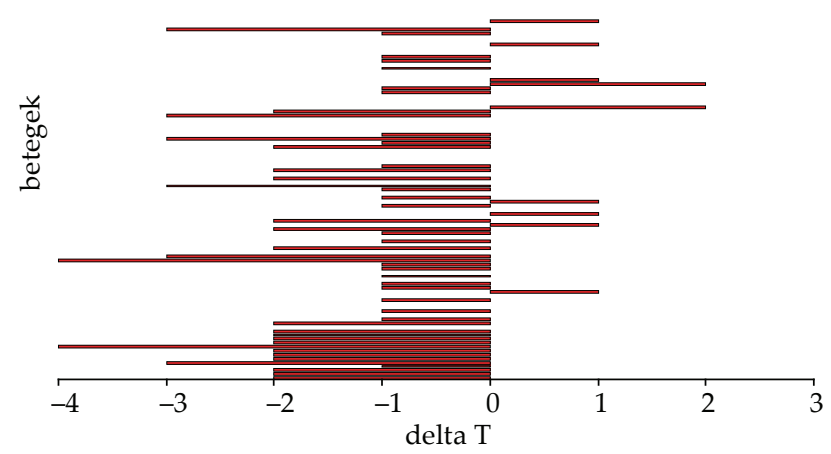

3. ábra. A T stádium változásának mértéke és iránya. A 0 pont a kezelés kezdetekor megállapított cT stádiumot jelzi, a változást ehhez képest a mütéti anyagban észlelt $p T$ stádium alapján állapítottuk meg. 
alapú kezelésben részesült betegek 29,1\%-ánál (7/24) volt megfigyelhető ehhez hasonló patológiai válasz. A kombinált kezelésben részesült betegek 12,1\%-a (4/33) reagált komplett vagy közel komplett remisszióval a kezelésre (5. táblázat).

Az emlőtumor-altípusokat és a neoadjuváns kezelésre adott választ együtt értékelve - az irodalmi adatokhoz hasonlóan - megfigyelhető, hogy a tripla negatív, valamint a HER2-pozitív szubtípusokba sorolt betegeknél mutatható ki a legnagyobb válaszkészség a neoadjuvánsan alkalmazott kemoterápiára. A pCR-t mutató HER2-pozitív daganatok közül 3 beteg kombinált terápiában, egy beteg antraciklin-alapú kezelésben részesült.

A preoperatívan felmért daganatjellemzők alapján a tripla negatív csoportba sorolt tumorok 33,3\%-ánál (9/27) volt kimutatható pCR (Chevallier I vagy II), az ER-/HER2+ daganatok esetében ez 10\% (1/10), az ER+/ HER2+ szubtípusban 30\% (3/10 eset), míg a luminalis A alcsoportba sorolt daganatok (ER+/HER2-) esetében pCR-t nem észleltünk. Megjegyzendő, hogy egy-egy szubtípust reprezentáló csoportba viszonylag kevés eset került (6. táblázat).

A posztoperatív tumormintákon végzett vizsgálatoknál figyelembe kell venni, hogy tizenhárom esetben pCR miatt nem tudtuk vizsgálni az ER-, PgR-, illetve HER2-státuszt. Ennek a kérdésnek feltehetően fontos szerepe lesz a jövőben a terápia megválasztásában. Vajon szükséges-e célzott terápiával illetve hormonterápi-

6. táblázat. A daganat preoperatív jellemzői alapján felállított immunfenotípusok és a neoadjuváns terápiára bekövetkezett patológiai válasz megítélése a Chevallier-osztályozás szerint

\begin{tabular}{lcc}
\hline \multicolumn{1}{c}{$\begin{array}{c}\text { Emlőtumor-altípusok } \\
\text { a preoperatív } \\
\text { diagnózis alapján }\end{array}$} & $\begin{array}{c}\text { Chevallier I-II } \\
\text { esetszám } \\
\text { (arány) }\end{array}$ & $\begin{array}{c}\text { Chevallier } \\
\text { III-IV } \\
\text { esetszám } \\
\text { (arány) }\end{array}$ \\
\hline Összes eset (92) & $13(14,1 \%)$ & $61(85,9 \%)$ \\
Tripla negatív (27) & $9(33,3 \%)$ & $18(66,6 \%)$ \\
HER2+ (10) & $1(10 \%)$ & $9(90 \%)$ \\
ER+/HER2- (27) & $0(0 \%)$ & $27(100 \%)$ \\
ER+/HER2+ (10) & $3(30 \%)$ & $7(70 \%)$ \\
Nem áll rendelkezésre elég & & \\
adat (18) & 0,001 & $<0,001$ \\
P (Monte Carlo) & & \\
\hline
\end{tabular}

7. táblázat. A posztoperatív mintán megállapított immunfenotípusok és a neoadjuváns terápiára bekövetkezett patológiai válasz megítélése a Chevallier III-IV csoportokban osztályozás szerint

\begin{tabular}{lcc}
\hline $\begin{array}{c}\text { Emlőtumor-altípusok } \\
\text { a posztoperatív } \\
\text { diagnózis alapján (összes) }\end{array}$ & $\begin{array}{c}\text { Chevallier III } \\
\text { esetszám } \\
\text { (arány) }\end{array}$ & $\begin{array}{c}\text { Chevallier IV } \\
\text { esetszám } \\
\text { (arány) }\end{array}$ \\
\hline Tripla negatív (20) & $13(65 \%)$ & $7(35 \%)$ \\
HER2+ (13) & $8(61,5 \%)$ & $5(38,5 \%)$ \\
Luminalis A ER+/HER2- (33) & $20(60,6 \%)$ & $13(39,4 \%)$ \\
Luminalis B ER+/HER2+ (12) & $9(75 \%)$ & $3(25 \%)$ \\
Nem áll rendelkezésre elég & & \\
adat (14) & & \\
\hline
\end{tabular}

ával kezelni műtét után a pCR státuszú beteget? Ezzel kapcsolatban még nincsenek megbízható adatok, mivel a pCR-t mutató betegek klinikai vizsgálatokba való bevonása nehezen tervezhető (klinikus megjegyzése). A tizenhárom daganat közül a preoperatív mintákon végzett elemzések alapján 9 tripla negatív daganat volt, egy eset HER2+, három további eset pedig ER+/HER2+ altípusnak felelt meg.

A mütéti anyagon (posztoperatív mintán) végzett immunhisztokémiai vizsgálatok alapján a Chevallier III és a Chevallier IV csoportba sorolt tumorokról rendelkezünk információkkal (7. táblázat). Ezek alapján a tripla negatív tumorok 65\%-ában (13/20) volt kimutatható látható elváltozás a kezelés következtében (Chevallier III), míg 35\%-ban nem vagy csak elenyésző változás volt kimutatható (Chevallier IV). A HER2pozitív daganatok 61,5\%-át (8/13) Chevallier III, míg $38,5 \%$-át (5/13) Chevallier IV csoportba soroltuk. Az ER+/HER2- szubtípusú daganatok 60,6\%-ában (20/33) és az ER+/HER2+ szubtípust mutató tumorok 75\%-ában (9/12) volt kimutatható látható elváltozás (Chevallier III) a neoadjuváns terápiát követően.

\section{MEGBESZÉLÉS}

A neoadjuváns terápia kedvező hatása a daganatmentes túlélésre számos tanulmány tárgya, és számos ellentmondás forrása egyben.

Egy 1998-ban készült tanulmány eredményei alapján nem találtak különbséget a teljes és betegségmentes túlélés szempontjából a neoadjuvánsan és posztoperatíven alkalmazott (adjuváns), de ugyanolyan típusú kezelés alkalmazása során (11). Az utóbbi években bevezetett kemoterápiás szereknek köszönhetően azonban a neoadjuváns terápia hatására bekövetkező regresszió és a patológiai komplett remisszió ( $\mathrm{pCR}$ ) szignifikánsan javítja a túlélést $(5,14)$.

Egy 2008-ban megjelent magyar tanulmány szerint (19) a neoadjuváns terápia hatása a túlélésre nem jobb az adjuváns kezelésénél, de segítheti a multimodális kezelés időben történő elkezdését. Mauri vizsgálatai szerint (24) a neoadjuváns szisztémás terápia a daganatos halálozás, a progresszió és a távoli metasztázisok kialakulása szempontjából nem különbözik az adjuváns terápiától, viszont a kezelés hatására bekövetkezett jó regresszió, különösen a pCR szignifikánsan javítja a prognózist. Saját vizsgálati anyagunkon, azzal együtt, hogy egy-egy betegcsoportba kevés beteg került, a pCR-t mutató csoportban a követési idő alatt jelentősen kevesebb recidíva és távoli áttét alakult ki. Az ebben a csoportban észlelt betegségspecifikus halálozást öszszehasonlítva azokkal a csoportokkal, ahol nem, vagy elenyésző patológiai válasz volt kimutatható az alkalmazott neoadjuváns kemoterápiára, szignifikáns különbséget találtunk. Ugyanakkor eredményeinkből az is látható, hogy a túlélés vonatkozásában az értékelhető patológiai válasz (Chevallier III) kedvező összehason- 
lítva a kezelésre egyáltalán nem reagáló tumorokkal. Megjegyzendő, hogy a betegek nagy része a 2007-2009es időszakból származik, ezért a túlélési adataink csak ennek figyelembevételével értékelhetők.

A neoadjuváns terápia jövője és egyben eredményessége talán abban rejlik, hogy mennyire vagyunk képesek meghatározni a különböző kezelési típusokra várható patológiai és klinikai választ, és ki tudjuk-e választani azokat a betegeket, akiknél ez a kezelési mód az optimális terápia. Azaz tudjuk-e definiálni azt a betegcsoportot, amely egyértelmúen profitál a neoadjuváns kezelésből.

A neoadjuváns terápia alkalmazása összetett feladat, szorosan együttmüködő multidiszciplináris munkacsoportot igényel, mert a betegek pontos és gyakori monitorozása szükséges. A daganatok egy része a neoadjuváns kezelés alatt is progrediálhat, mely a tervezettnél korábbi mütéti beavatkozást tesz szükségessé, illetve ezeket a betegeket a továbbiakban lehetőség szerint klinikai vizsgálatok keretein belül kell kezelni. Bár saját betegeink között 9 esetben a klinikai vizsgálatokkal megállapított $\mathrm{T}$ stádiumhoz képest a mütéti anyagban megállapított $\mathrm{pT}$ stádium magasabb volt, nem tartottuk progressziónak eseteinket, mivel a képalkotók által leírt tumorméret változatlan maradt a kezelés kezdetétől a mütétig. Tisztázatlan még, hogy a progrediáló betegek számára nem jelent-e hátrányt a "sikertelen" kezelés, rontja-e gyógyulási, túlélési esélyüket az időveszteség? Felmerül az a kérdés is, hogy mennyire hátráltatják a kezelés következtében kialakult mellékhatások a mütéti beavatkozás időpontját, bár az utolsó ciklus kemoterápia és a mütét közötti 2-3 hét szinte minden esetben elegendőnek bizonyul az esetleges eltérések rendezésére. Emellett pCR esetében a tumor pontos elhelyezkedése nehezebben ítélhető meg (29), mely miatt fontos a kezelés kezdetekor a tumor helyének pontos megjelölése, amikor még a képalkotó eljárásokkal lokalizálható.

Annak ellenére, hogy a neoadjuváns terápia alkalmazásában a pCR elérése az elsődleges cél, a különböző munkacsoportok által végzett vizsgálatok összehasonlítását nehezíti, hogy nincsen konszenzus a pCR pontos megállapítására. Előreláthatóan az EU vonatkozó Guideline-jának következő kiadásában a Pinder által ajánlott (28), a Sataloff-sémával lényegében azonos beosztást fogja javasolni (az EWGBSP értekezletén elhangzott személyes közlés), amit az indokol, hogy ebben az osztályozásban a nyirokcsomóstátusz és ennek változása a kezelés hatására pontosabban tükröződik.

Az általunk vizsgált betegcsoportban az antraciklinalapú kezelésben részesült betegek 6,6\%-ánál volt kimutatható patológiai remisszió, a taxán-kezelésben részesült betegek 29,1\%-ánál, míg a kombinált kezelésben részesült betegek 12,1\%-ánál volt megfigyelhető a teljes vagy majdnem teljes patológiai válasz (Chevallier I vagy II). Kezdetben a hagyományos kemoterápiás kezelési protokollokat alkalmazva a pCR csupán néhány százalék volt, ami a második generációs kemoterápiás szerek bevezetésével 20\% körüli értékre emelkedett (16). A neoadjuváns kemoterápiáról megjelent NSABP B-27 tanulmányban megfigyelt pCR az alkalmazott kemoterápiás protokollok tükrében $14-26 \%$ (ACx4 vs. ACx4 $\rightarrow$ 4xD), míg a GEPAR-DUO II néven ismertté vált vizsgálatban ez az arány $23-12 \%$ (ACx4 $\rightarrow$ Dx4 vs.2wADx4) (18).

Annak eldöntéséhez, hogy vajon a neoadjuváns terápia-e az optimális kezelési mód egy adott beteg esetében, segítségünkre lehetnek olyan markerek, melyek kellő megbízhatósággal jelzik a kedvező terápiás választ, elsősorban a pCR-t. Az ezen a téren végzett fontosabb vizsgálatok alapján három kategóriába lehet sorolni azokat az információkat és markereket, amelyek előre jelezhetik a pCR valószínűségét (29). Ezek a következők: 1) klinikai válasz megítélése két kezelési ciklust követően, 2) klinikai megjelenés (clinical phenothype), valamint 3) molekuláris markerek (HER2-, ER-, PgR-státusz, Ki-67 vagy Oncotype DX). Különböző modelleket dolgoztak ki ezeknek az adatoknak az összesítésére, a pCR valószínüségének becslésére, melyek közül az MD Anderson Cancer Center közel 1000 beteg adatának feldolgozásával dolgozott ki egy nomogramot, mely ingyenesen elérhetô a http://www.mdanderson.org/ care_centers/breastcenter/dIndex.cfm?pn=448442B2-3EA5-4BAC-98310076A9553E63 oldalon.

$\mathrm{Az}$ eddigi tapasztalatok szerint a neoadjuváns terápia hatékonysága a tripla negatív tumorokban és a HER2-pozitív daganatokban a legmagasabb, míg az ER-pozitív esetekben 10\% alatt marad (29). Az általunk vizsgált betegcsoportban a preoperatív mintákon végzett elemzések alapján a tripla negatív tumorok 33,3\%ánál (9/27), míg az ER-/HER2-pozitív daganatok 10\%ánál $(1 / 10)$ volt kimutatható jelentős patológiai válasz. Megfigyelhető az is, hogy az ER+/HER2+ csoportba sorolt daganatok nagyobb válaszkészséggel rendelkeznek az alkalmazott neoadjuváns terápiára, összehasonlítva az ER+/HER2- csoporttal, melyben nagy valószínüséggel szerepet játszik HER2-pozitivitásuk. Ezeknek az eredményeknek a tükrében a tumorok indirekt molekuláris biológiai jellemzése, azaz az immunfenotípuscsoportok meghatározása a napi rutin diagnosztika szintjén pontosabb prediktív információt ad egy-egy kemoterápiás séma várható eredményességéről.

Továbbra is kérdés azonban, hogy a pCR mennyire jelezheti előre a betegségmentes túlélést vagy az össztúlélést, különösen, ha a tripla negatív daganatok közismerten agresszívebb viselkedésére gondolunk. Wolff és munkacsoportja (39) megállapította, hogy a pCR jelentős prediktív faktor a betegek össztúlélését illetően. Egyes szerzők szerint a pCR prediktív lehet az össztúlélés megítélésében függetlenül attól, hogy antraciklin- vagy taxán-alapú kemoterápiát alkalmaztak $(3,11)$.

Továbbra is fontos kérdések várnak válaszra a neoadjuváns kemoterápia alkalmazásával és indikációival kapcsolatban. Eseteink elemzésével a pontos patológiai lelet prediktív értékére is fel szeretnénk 
hívni a figyelmet. Úgy gondoljuk, hogy addig is, amíg a molekuláris tesztek a napi rutin diagnosztika szintjén elérhetővé válnak, a hagyományosan elvégzett immunhisztokémiai vizsgálatok helyes értelmezése nagy segítséget adhat a kezelések tervezésével kapcsolatban. Számos további kérdés is nyitott a neoadjuváns kemoterápia klinikai, patológiai vonatkozásait és molekuláris patológiai vonatkozásait tekintve, pl. az alkalmazott protokollokat, a neoadjuváns kemoterápia eredményességét, a terápiás hatás értékelési sémáit, a terápiarezisztenciában szerepet játszó faktorok kimutatását illetően. Klinikai szempontból talán a legérdekesebb a pCR utáni további kemoterápia, célzott illetve endokrin terápia, valamint a sugárterápia kérdése.

\section{KÖSZÖNETNYILVÁNÍTÁS}

Munkánkhoz az alábbi pályázatok forrásait használtuk: NKFP-1A/0023/2002, AVON-EAGC 2005, MKOT-GSK 2006, MKOT-GSK 2008.

\section{IRODALOM}

1. Baselga J, Semiglazov V, Manikhas GM, et al. Efficacy of neoadjuvant trastuzumab in patients with inflammatory breast cancer: data from the NOAH (Neoadjuvant Herceptin) phase III trial. Eur J Cancer 5:193 [abstract 2030], 2007

2. Bear HD, Anderson S, Brown A, et al. The effect on tumor response of adding sequential preoperative docetaxel to preoperative doxorubicin and cyclophosphamide: preliminary results from National Surgical Adjuvant Breast and Bowel Project Protocol B-27. J Clin Oncol 21:4165-4174, 2003

3. Bear HD, Anderson S, Smith RE, et al. Sequential preoperative or postoperative docetaxel added to preoperative doxorubicin plus cyclophosphamide for operable breast cancer: National Surgical Adjuvant Breast and Bowel Project Protocol B-27. J Clin Oncol 24:2019-2027, 2006

4. Buzdar AU, Valero V, Ibrahim NK, et al. Neoadjuvant therapy with paclitaxel followed by 5 -fluorouracil, epirubicin, and cyclophosphamide chemotherapy and concurrent trastuzumab in human epidermal growth factor receptor 2-positive operable breast cancer: an update of the initial randomized study population and data of additional patients treated with the same regimen. Clin Cancer Res 13:228-233, 2007

5. Capirci C, Valentini V, Cionini L, et al. Prognostic value of pathologic complete response after neoadjuvant therapy in locally advanced rectal cancer: long-term analysis of $566 \mathrm{ypCR}$ patients. Int J Radiat Oncol Biol Phys 72:99-107, 2008

6. Carey LA, Dees EC, Sawyer L, et al. The triple negative paradox: primary tumor chemosensitivity of breast cancer subtypes. Clin Cancer Res 13:2329-2334, 2007

7. Carey LA, Metzger R, Dees EC, et al. American Joint Committee on Cancer tumor-node-metastasis stage after neoadjuvant chemotherapy and breast cancer outcome. J Natl Cancer Inst 97:1137-1142, 2005

8. Chevallier B, Roche H, Olivier JP, et al. Inflammatory breast cancer. Pilot study of intensive induction chemotherapy (FEC-HD) results in a high histologic response rate. Am J Clin Oncol 16:223228, 1993

9. Dank M, Zergenyi E, Domotori ZS, et al. Primary systemic therapy (PST) of locally advanced breast cancer using Doxorubicin/ Docetaxel combination. Anticancer Res 23:2879-2880, 2003
10. Feldman LD, Hortobagyi GN, Buzdar AU, et al. Pathological assessment of response to induction chemotherapy in breast cancer. Cancer Res 46:2578-2581, 1986

11. Fisher B, Bryant J, Wolmark N, et al. Effect of preoperative chemotherapy on the outcome of women with operable breast cancer. J Clin Oncol 16:2672-2685, 1998

12. Gianni L, Eiermann W, Semiglazov V, et al. Neoadjuvant trastuzumab in patients with her2-positive locally advanced breast cancer: primary efficacy analysis of the noah trial. Presented at the 31st Annual San Antonio Breast Cancer Symposium, 2008 www.abstracts2view.com/sabcs/view. php?nu=SABCS08L_1443\&terms

13. Gralow JR, Burstein HJ, Wood W, et al. Preoperative therapy in invasive breast cancer: pathologic assessment and systemic therapy issues in operable disease. J Clin Oncol 26:814-819, 2008

14. Guarneri V, Broglio K, Kau SW, et al. Prognostic value of pathologic complete response after primary chemotherapy in relation to hormone receptor status and other factors. J Clin Oncol 24:1037-1044, 2006

15. Hammock L, Lewis M, Phillips C, et al. Strong HER-2/neu protein overexpression by immunohistochemistry often does not predict oncogene amplification by fluorescence in situ hybridization. Hum Pathol 34:1043-1047, 2003

16. Hayward JL, Carbone PP, Heusen JC, et al. Assessment of response to therapy in advanced breast cancer. Br J Cancer 35:292-298, 1977

17. Hennessy BT, Hortobagyi GN, Rouzier R, et al. Outcome after pathologic complete eradication of cytologically proven breast cancer axillary node metastases following primary chemotherapy. J Clin Oncol 23:9304-9311, 2005

18. Heys SD, Sarkar T, Hutcheon AW. Primary docetaxel chemotherapy in patients with breast cancer: impact on response and survival. Breast Cancer Res Treat 90:169-185, 2005

19. Kahán Zs, Nikolényi A, Uhercsák G, Thurzó L. Neoadjuváns szisztémás terápia emlőrákban. Orvosi Hetilap 150:65-71, 2009

20. Kaplan EL, Meier P. Nonparametric estimation from incomplete observations. J Am Stat Assoc 53:457-481, 1958

21. Kaufmann M, von Minckwitz G, Smith R, et al. International expert panel on the use of primary (preoperative) systemic treatment of operable breast cancer: review and recommendations. J Clin Oncol 21:2600-2608, 2003

22. Liedtke C, Mazouni C, Hess KR, et al. Response to neoadjuvant therapy and long term survival in patients with triple-negative breast cancer. J Clin Oncol 26:1275-1281, 2008

23. Mamounas EP. Overview of National Surgical Adjuvant Breast Project neoadjuvant chemotherapy studies. Semin Oncol 25:3135,1998

24. Mauri D, Pavlidis N, Ioannidis JP. Neoadjuvant versus adjuvant systemic treatment in breast cancer: a meta-analysis. J Natl Cancer Inst 97:188-194, 2005

25. Ogston KN, Miller ID, Payne S, et al. A new histological grading system to assess response of breast cancers to primary chemotherapy: prognostic significance and survival. Breast 12:320-327, 2003

26. Peintinger F, Buzdar AU, Kuerer HM, et al. Hormone receptor status and pathologic response of HER2-positive breast cancer treated with neoadjuvant chemotherapy and trastuzumab. Ann Oncol 19:2020-2025, 2008

27. Penault-Llorca F, Abrial C, Raoelfils I, et al. Comparison of the prognostic significance of Chevallier and Sataloff's pathologic classifications after neoadjuvant chemotherapy of operable breast cancer. Hum Pathol 39:1221-1228, 2008

28. Pinder SE, Provenzano E, Earl H, et al. Laboratory handling and histology reporting of breast specimens from patients who have received neoadjuvant chemotherapy. Histopathology 50:409-417, 2007

29. Pusztai L. Preoperative systemic chemotherapy and pathologic assessment of response. Pathol Oncol Res 14:169-171, 2008

30. Reis-Filho JS, Tutt AN. Triple negative tumours: a critical review. Histopathology 52:108-118, 2008

31. Ring AE, Ellis PA. Predictors of response to systemic therapy in breast cancer. Forum (Genova) 12:19-32, 2002

32. Ring AE, Smith IE, Ashley S, et al. Oestrogen receptor status, pathological complete response and prognosis in patients receiv- 
ing neoadjuvant chemotherapy for early breast cancer. Br J Cancer 91:2012-2017, 2004

33. Sanchez-Munoz A, Garcia-Tapiador AM, Martinez-Ortega E, et al. Tumour molecular subtyping according to hormone receptors and HER2 status defines different pathological complete response to neoadjuvant chemotherapy in patients with locally advanced breast cancer. Clin Transl Oncol 10:646-653, 2008

34. Sataloff DM, Mason BA, Prestipino AJ, et al. Pathologic response to induction chemotherapy in locally advanced carcinoma of the breast: a determinant of outcome. J Am Coll Surg 180:297-306, 1995

35. Straver ME, Glas AM, Hannemann J, et al. The 70-gene signature as a response predictor for neoadjuvant chemotherapy in breast cancer. Breast Cancer Res Treat, 2009

36. Straver ME, van Adrichem JC, Rutgers EJ, et al. Neoadjuvant systemic therapy in patients with operable primary breast cancer: more benefits than breast-conserving therapy. Ned Tijdschr Geneeskd 152:2519-2525, 2008

37. Tokes AM, Szasz AM, Farkas A, et al. Stromal matrix protein expression following preoperative systemic therapy in breast cancer. Clin Cancer Res 15:731-739, 2009

38. Wang S, Yang H, Tong F, et al. Response to neoadjuvant therapy and disease free survival in patients with triple-negative breast cancer. Gan To Kagaku Ryoho 36:255-258, 2009

39. Wolff AC, Davidson NE. Preoperative therapy in breast cancer: lessons from the treatment of locally advanced disease. Oncologist 7:239-245, 2002

40. Wolff AC, Hammond ME, Schwartz JN, et al. American Society of Clinical Oncology/College of American Pathologists guideline recommendations for human epidermal growth factor receptor 2 testing in breast cancer. J Clin Oncol 25:118-145, 2007 